\title{
Lipolysis Exposes Unreactive Endogenous Apolipoprotein E-3 in Human and Rat Plasma Very Low Density Lipoprotein
}

\author{
Ephraim Sehayek, Uria Lewin-Velvert, Tova Chajek-Shaul, and Shlomo Eisenberg \\ Lipid Research Laboratory, Department of Medicine B, Hadassah University Hospital, Jerusalem, il-91120, Israel
}

\begin{abstract}
Endogenous apolipoprotein E in VLDL is poorly expressed in receptor binding processes. Yet catabolism of VLDL-remnants by cellular receptors depends on functional apo $\mathrm{E}$ molecules. To better understand remnant catabolism phenomena, we determined the metabolism of VLDL and post-lipolysis VLDL by cultured cells. Partial lipolysis was achieved by incubation of VLDL with lipoprotein lipase in vitro (human) or recirculation (rat) in supradiaphragmatic animals. Lipolyzed VLDL exhibit metabolic activities 2-20-fold higher than control VLDL, that are saturable and dependent on the presence of $L D L$ receptors. The ligand responsible for receptor interaction of lipolyzed VLDL (apo E or apo B-100) and its source (endogenous or transferred) was studied with monoclonal antibodies and with lipoproteins from E-3/3 and E-2/2 subjects. The data unequivocally proved that lipolysis causes exposure of unreactive endogenous apo E-3 at the VLDL surface, possibly by a change of conformation of the protein. Apo B-100 becomes biologically expressed only in lipolyzed VLDL-III. Lipolyzed VLDL, however, is less reactive to exogenous apo E-3 than control VLDL indicating that endogenous and exogenous apo $\mathbf{E}$ are oriented differently in VLDL. It is proposed that VLDL delivers triglycerides to tissues when apo $E$ is unreactive but becomes a remnant after the protein becomes exposed and directs the particles from lipoprotein lipase sites to cellular receptors. (J. Clin. Invest. 1991. 88:553-560.) Key words: VLDL remnants $\bullet$ LDL receptor $\bullet$ triglyceride transport $\bullet$ apolipoprotein B-100 • lipoprotein lipase
\end{abstract}

\section{Introduction}

Irreversible uptake and degradation in liver and other cell types of VLDL (apo B-100) remnants is believed to be a major pathway that regulates LDL formation through the VLDL-IDLLDL cascade (1-3). For example, avid VLDL remnant catabolism is responsible for the paucity of LDL particle number in rats (4) and other experimental animals (5). A similar process, albeit less pronounced, appears also to operate in humans, especially patients with hypertriglyceridemia (6). Neither the physical and chemical characteristics of remnant particles nor the

Part of this investigation has been published in abstract form (1990. Arteriosclerosis. 10:798).

Address correspondence and reprint requests to Shlomo Eisenberg, M.D., Dept. of Medicine B, Hadassah University Hospital, Jerusalem, Israel.

Received for publication 12 December 1990 and in revised form 14 March 1991.

J. Clin. Invest.

(C) The American Society for Clinical Investigation, Inc.

0021-9738/91/08/0553/08 \$2.00

Volume 88, August 1991, 553-560 exact nature of the ligand and receptor(s) involved with their uptake are clear. Nevertheless it is well established that presence of functional apo E molecules (E-3 and/or E-4) is essential for normal remnant uptake processes $(7,8)$.

Apolipoprotein $\mathrm{E}$ is an integral protein constituent of plasma VLDL and IDL. Yet we and others have demonstrated that interactions of human plasma VLDL and IDL with the fibroblast LDL receptor (9-12) or of rabbit $\beta$-VLDL with the LDL-receptor-related protein (13) is minimal unless the lipoproteins are enriched with exogenous apo E-3. It thus appears that endogenous apo E associated with circulating lipoprotein particles is perhaps not fully expressed in receptor uptake processes; the apo E molecules however must become available for receptor interactions after metabolic alterations of the lipoproteins. In the present report we demonstrate that lipoprotein lipase induced lipolysis of VLDL exposes unreactive endogenous apo E-3 molecules on the lipoprotein surface and initiates receptor mediated catabolism of the VLDL. A similar process, if occurring in vivo may provide a novel mechanism that regulates triglyceride transport, remnant catabolism, and LDL synthesis along the VLDL $\rightarrow$ IDL $\rightarrow$ LDL apo B-100 cascade.

\section{Methods}

Isolation and characterization of $V L D L$ and $L D L$. Blood was collected in EDTA $(1 \mathrm{mg} / \mathrm{ml})$ from 17 normolipidemic apo E-3/3 or $4 / 3$ human subjects after $12-14 \mathrm{~h}$ fast and plasma was separated promptly at $4^{\circ} \mathrm{C}$. VLDL was separated on the same day at plasma density $(1.006 \mathrm{~g} / \mathrm{ml})$ by centrifugation in a $60 \mathrm{Ti}$ rotor at $45,000 \mathrm{rpm}, 4^{\circ} \mathrm{C}$, in a model L5-50 ultracentrifuge (Beckman Instruments, Inc., Fullerton, CA) and the VLDL was spun once more at density of $1.006 \mathrm{~g} / \mathrm{ml}$. VLDL density subfractions I-III were prepared on a $\mathrm{NaCl}$ gradient in an SW-41 rotor after the procedure of Lindgren et al. (14). LDL was separated at density interval of $1.019-1.063 \mathrm{~g} / \mathrm{ml}$ and $\mathrm{HDL}_{3}$, at density interval of $1.125-1.21 \mathrm{~g} / \mathrm{ml}$. The lipoproteins were dialyzed against $0.15 \% \mathrm{NaCl}$, $20 \mathrm{mM}$ Tris (pH 7.4), $0.001 \%$ EDTA solution, were sterilized by passage through a $0.45-\mu \mathrm{m}$ filter (Millipore Corp., Bedford, MA) and used within $10 \mathrm{~d}$ of preparation. Rat plasma VLDL was prepared likewise from plasma obtained after overnight fast. Lipoprotein protein, total, free, and esterified cholesterol and phospholipids were determined by standard procedures (11). Triglycerides and nonesterified fatty acids were determined enzymatically (Raichem, Reagents Applications Inc., San Diego, CA, and NEFA-C, Wako, Osaka, Japan). SDS-PAGE of apolipoproteins on $10 \%$ gels was performed after the methods described by Weber and Osborn (15). Human recombinant apo E-3 was made in bacteria (16) and is a generous gift of Biotechnology General, Rehovot, Iśrael.

Iodination of $V L D L$ and $L D L .{ }^{125}$ I-labeled VLDL and LDL were prepared by the iodine monocholoride method of MacFarlane (17) as modified by Bilheimer et al. (18). The iodinated preparations were dialyzed extensively against $0.15 \mathrm{M} \mathrm{NaCl}, 0.001 \%$ EDTA, pH 7.4. The final specific activity varied between 300 and $600 \mathrm{cpm} / \mathrm{ng}$ protein and $50-500 \mathrm{cpm} / \mathrm{ng}$ protein for VLDL and LDL, respectively. In all preparations, $>95 \%$ of the radioactivity was precipitated by TCA and $<5 \%$ was extractable by chloroform-methanol. Labeled apoproteins in lipo- 
proteins were determined after SDS-PAGE of ${ }^{125}$ I-labeled lipoproteins and counting of gel slices.

Preparation of lipolyzed VLDL. Lipolysis of human ${ }^{125}$ I-VLDL was achieved by in vitro incubation with bovine milk lipoprotein lipase as previously described (19). The incubation mixture contained VLDL (1-2 mg protein, $5-10 \mathrm{mg}$ triglycerides), human $\mathrm{HDL}_{3}$ (10 mg protein) and $200 \mathrm{mg}$ of fatty acid poor BSA (Sigma Chemical Co., St. Louis, $\mathrm{MO}$ ) in $0.05 \mathrm{M}$ Tris buffer $\mathrm{pH} 8.2$ and $0.15 \mathrm{M} \mathrm{NaCl}$. 5-20 $\mu$ l of purified bovine milk lipoprotein lipase were added and the incubation was carried out in a shaking water bath at $37^{\circ} \mathrm{C}$ for $10-20 \mathrm{~min}$, until partial or complete clearance of the mixtures was observed. Lipolysis was stopped by increasing the density of the medium to $1.055 \mathrm{~g} / \mathrm{ml}$ with solid $\mathrm{KBr}$. A control (unlipolyzed) ${ }^{125} \mathrm{I}-\mathrm{VLDL}$ was prepared in parallel using exactly the same procedure but without lipoprotein lipase. The lipolyzed and control VLDL were separated by a single centrifugation at $35,000 \mathrm{rpm}$ for $18 \mathrm{~h}$ at $4^{\circ} \mathrm{C}$, isolated by the tube slicing technique and dialyzed extensively against $0.15 \mathrm{M} \mathrm{NaCl}, 0.02 \mathrm{M}$ Tris, $0.001 \%$ EDTA, pH 7.4 solution. ${ }^{125} \mathrm{I}-\mathrm{ApoB}-100$ in the original, control and lipolyzed ${ }^{125} \mathrm{I}-\mathrm{VLDL}$ was determined by SDS-PAGE and the lipoproteins were used for cell metabolism studies according to their apo B-100 content. Apo B-100 mass in the VLDLs was derived from radioactivity counts in apo B and the specific activity of VLDL-apoproteins. Degrees of lipolysis were calculated as percent of unesterified fatty acids generated in the samples containing lipoprotein lipase. Lipolysis-induced density change of VLDL was assessed by radioactivity profiles of aliquots of control and lipolyzed ${ }^{125}$ I-VLDL eluted in a zonal ultracentrifugation system after 45 min centrifugation in a $\mathrm{NaCl}$ gradient of density $1.0-1.15 \% \mathrm{~g} / \mathrm{ml}$ at $42,000 \mathrm{rpm}$ (19). Lipolysis of rat VLDL was carried out in supradiaphragmatic rats. After the operation (20), ${ }^{125}$ I rat VLDL was injected intravenously and the rats were allowed to recover and to move freely in the cage. A bolus of $10 \%$ glucose solution was injected IV every 15-30 min through a catheter in a tail vein. The rats were exanguinated through the abdominal aorta at the end of $2 \mathrm{~h}$ from the injection of the ${ }^{125} \mathrm{I}-\mathrm{VLDL}$. The lipolyzed ${ }^{125} \mathrm{I}-\mathrm{VLDL}$ was separated and used as described above, except that centrifugation was carried out at salt density of $1.019 \mathrm{~g} / \mathrm{ml}$. Control ${ }^{125} \mathrm{I}-\mathrm{VLDL}$ was prepared likewise from the plasma of supradiaphragmatic rats exanguinated $1 \mathrm{~min}$ after the injection.

Binding, cell association, and degradation of ${ }^{125}$ I-lipoproteins. $\mathrm{Hu}-$ man skin fibroblasts were prepared from skin biopsies obtained from the medial part of the forearm of normal adult male donors (21). The cells were cultured in plastic flasks (Falcon Labware; Division of Becton Dickinson \& Co., Oxland, CA) in modified Dulbecco-Vogt medium containing $10 \%$ FCS and maintained in a humidified incubator $\left(5 \% \mathrm{CO}_{2}\right)$ at $37^{\circ} \mathrm{C}$. Fibroblasts from three to 15 subcultures were used. After trypsinization, $3.5 \times 10^{4}$ cells were plated in $35-\mathrm{mm}$ dishes (Falcon Labware), and grown in $2 \mathrm{ml}$ medium with $10 \%$ FCS. The medium was changed every $2 \mathrm{~d}$ while the cells were not yet confluent. On the fifth or seventh day, monolayers were washed with PBS buffer and incubated for $48 \mathrm{~h}$ in $2 \mathrm{ml}$ of fresh medium containing human lipoprotein-deficient serum (LPDS) ${ }^{1}$ at a final protein concentration of $5 \mathrm{mg} /$ $\mathrm{ml}$. After $48 \mathrm{~h}$ incubation with LPDS medium, the cells were used for further experiments. Cultured rat skin fibroblasts were prepared likewise, from skin biopsies obtained from male rats. HepG-2 cultures were prepared as previously described (12) except that the cells were grown in 35-mm dishes as above.

Binding, cell association, and proteolytic degradation of ${ }^{125}$ I-labeled lipoproteins were determined as previously described (21). On the day of experiment, the fresh medium was removed and the cells were incubated at $37^{\circ} \mathrm{C}$ with LPDS medium containing lipolyzed or control ${ }^{125} \mathrm{I}$-VLDL-I, -II, or -III (apo B-100 equivalent to $10 \mu \mathrm{g}$ protein $/ \mathrm{ml}$ ). Exogenous recombinant apo E-3 at a concentration of $4 \mu \mathrm{g} / \mathrm{ml}$ was added to culture dishes containing the ${ }^{125} \mathrm{I}-\mathrm{VLDL}$ populations while buffer alone was added to the samples not enriched with apo E-3. After $6 \mathrm{~h}$ incubation at $37^{\circ} \mathrm{C}$ the medium was removed and examined for

1. Abbreviation used in this paper: LPDS, lipoprotein-deficient serum. noniodide ${ }^{125}$ I-protein degradation products (22). Fresh ice-cold LPDS medium was added to the cells and the cells were washed extensively with ice-cold PBS buffer containing $0.2 \%$ BSA. The amount of ${ }^{125} \mathrm{I}$-lipoproteins bound to the cells was determined by the release of radioactivity after incubation of the washed cells at $4^{\circ} \mathrm{C}$ with medium containing $10 \mathrm{mg} / \mathrm{ml}$ of sodium heparin for $1 \mathrm{~h}$, according to Goldstein et al. (22). Labeled lipids in the cells were extracted with chloroform-methanol $(1: 1, \mathrm{vol} / \mathrm{vol})$ and the cell residue was dissolved in $1 \mathrm{ml}$ of $0.5 \mathrm{~N}$ $\mathrm{NaOH}$. Cell-associated lipoprotein-protein was determined as radioactivity remaining in the delipidated cells. Dishes without cells and cultures incubated in the presence of 40 -fold excess of unlabeled lipoproteins (nonspecific values) were processed in parallel to the experimental samples. Results are expressed as nanograms of ${ }^{125} \mathrm{I}$-apo B-100 protein bound, associated or degraded per milligram of cell protein after subtraction of blank (cell free) and nonspecific values.

Monoclonal antibodies. Monoclonal antibodies that specifically block the ligand binding domain of apo B-100 (antibody 4G3) or apo E (antibody 1D7) are a generous gift of Drs. Marcel and Milne. The characteristics of the antibodies are described elsewhere (23).

Materials. Na- ${ }^{125}$ I was purchased from the Radiochemical Centre, Amersham, UK. Culture flasks and dishes were obtained from Falcon Labware. Medium and FCS were obtained from Gibco Laboratories, Grand Island, NY. All other chemicals and reagents were of analytical grade.

\section{Results}

Examples of SDS-PAGE of control and lipolyzed human and rat VLDL apoproteins are shown in Fig. 1. After lipolysis, the VLDL retained its apo $B$ and apo $E$ moieties but appeared to lose $\mathrm{C}$ apoproteins. Radioactive apoproteins in control-incubated and lipoprotein lipase-incubated human VLDL-I, II, and III and control and lipolyzed rat VLDL are shown in Table I. Most of the radioactivity was associated with apo B and apo C; only trace amounts were found in apo $\mathrm{E}$. Lipolysis caused loss of ${ }^{125} \mathrm{I}$-apo $\mathrm{C}$ from the VLDL and relative enrichment of the lipoprotein with ${ }^{125} \mathrm{I}$-apo $\mathrm{B}$. The ${ }^{125} \mathrm{I}$-apo $\mathrm{B}$ to ${ }^{125} \mathrm{I}$-apo $\mathrm{C}$ ratio in human VLDL increased by an average of 45 to $72 \%$ (mean, $63 \%$ ) and in rat VLDL, by $140 \%$. Assuming that apo C loss from VLDL is linear with the degree of lipolysis (24) this change of ${ }^{125} \mathrm{I}$-apo $\mathrm{B}$ to ${ }^{125} \mathrm{I}$-apo $\mathrm{C}$ ratio indicates triglyceride hydrolysis of $\sim 40 \%$ in human VLDL and $\sim 70 \%$ in rat VLDL. Apo E to apo B mass ratios in control and lipolyzed

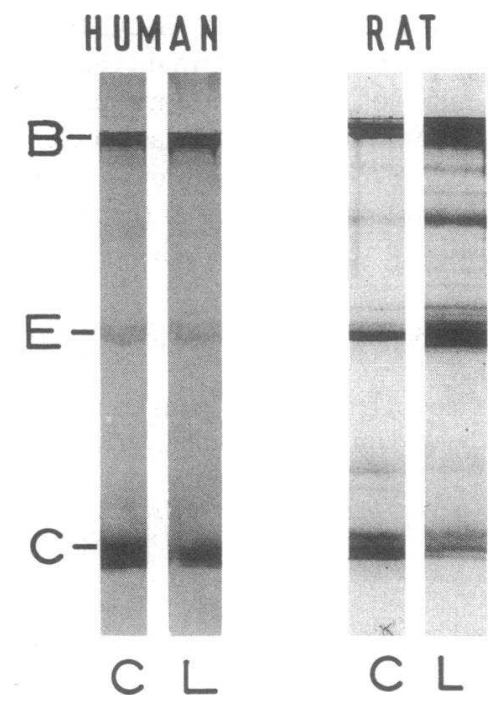

Figure 1. SDS-PAGE of control $(C)$ and lipolyzed $(L)$ human and rat VLDL. Triglyceride hydrolysis, $40 \%$ (human) and $75 \%$ (rat). 
Table I. Distribution of ${ }^{125}$ I-Apo B and ${ }^{125}$ I-Apo C in Control and Lipolyzed VLDL

\begin{tabular}{lcclll}
\hline & \multicolumn{2}{c}{${ }^{125}$ I-Apo B } & & \multicolumn{2}{c}{${ }^{125}$ I-Apo C } \\
\cline { 2 - 3 } \cline { 5 - 6 } Lipoprotein & Control & Lipolyzed & & Control & Lipolyzed \\
\hline & \multicolumn{4}{c}{ \% of total gel radioactivity } \\
VLDL-I & $39.3 \pm 2.3$ & $46.7 \pm 9.3$ & & $47.5 \pm 5.0$ & $38.9 \pm 9.9$ \\
VLDL-II & $45.6 \pm 9.0$ & $55.5 \pm 9.4$ & & $36.1 \pm 11.3$ & $26.4 \pm 9.9$ \\
VLDL-III & $57.8 \pm 7.9$ & $65.6 \pm 8.1$ & & $28.5 \pm 6.2$ & $18.8 \pm 8.8$ \\
Rat VLDL & $27.2 \pm 4.9$ & $40.7 \pm 11.2$ & & $46.7 \pm 6.2$ & $29.2 \pm 8.4$
\end{tabular}

Data are means $\pm S E$ of 4-8 control and lipolyzed VLDL preparations. Percent radioactivity in apo $B$ and apo $C$ was determined after SDSPAGE of control and lipolyzed ${ }^{125} \mathrm{I}-\mathrm{VLDL}$ and counting gel slices as described in Methods.

VLDL as determined by scanning SDS-PAGE gels were $0.21 \pm 0.07$ and $0.19 \pm 0.08$ (mean \pm SD of 15 preparations), respectively.

The degree of lipolysis, as estimated by generation of free fatty acids ranged between $19.6-80.0 \%$, with a mean of $38.7 \%$. The cholesteryl ester to triglyceride ratio in lipolyzed VLDL increased by $10-100 \%$, a finding that agrees with the degrees of lipolysis (assuming that the cholesteryl ester content of the VLDL is not affected by lipolysis). The effects of lipolysis on VLDL were also assessed by centrifugation in a zonal rotor (data not shown). As previously described (19), a shift of the lipoproteins towards smaller and denser particle population was evident after the incubation with lipoprotein lipase. The position of the lipolyzed VLDL peak varied with the degree of lipolysis, being late with preparations that underwent more vigorous lipolysis. After the incubation radioactivity was associated with HDL (data not shown) due to exchange of labeled apo $C$ between the VLDL and HDL. HDL radioactivity increased considerably in incubations with lipoprotein lipase reflecting transfer of labeled apo $\mathrm{C}$ from the lipolyzed VLDL to HDL. The amount of free fatty acids associated with lipolyzed VLDL was assessed by thin layer chromatography of neutral lipids (24). No, or only minimal change was observed.

Binding, cell association, and degradation of control and lipolyzed human VLDL-I, II, and III were determined in cul- tured fibroblasts after $6 \mathrm{~h}$ of incubation without and with exogenous apo E-3. Control VLDL without added apo E-3 exhibits very low metabolic activities (binding, cell association, and degradation) that as previously reported (11), are enhanced 10-30fold (degradation) by the addition of exogenous apo E-3 (Table II). The behavior of lipolyzed VLDL was distinctly different in two respects. First, a pronounced metabolic activity of the lipolyzed particles without added apo E-3 was observed. Binding and cell association were two to fourfold higher and proteolytic degradation, 5-20-fold higher than control VLDL. For some preparations, in particular VLDL-I, the metabolic activity of the lipolyzed lipoprotein not supplemented with apo E-3 was higher than the corresponding control VLDL maximally stimulated by exogenous apo E-3. Second is the relative response to exogenous apo E-3 that for the lipolyzed particles was only one-half to threefold higher than that of the same preparations not enriched with apo E-3. It thus appears that lipolysis exposes on VLDL binding sites to the fibroblast receptor that are largely not expressed in the intact particle; the further stimulation of cell metabolism of the lipoprotein by exogenous apo E-3, however, is limited. Similar observations were made in HepG-2 cultures (Table III). Two additional control experiments were performed. In the first, unlabeled lipolyzed VLDL was prepared and incubated together with biosynthetically labeled $\left[{ }^{3} \mathrm{H}\right]-T G$ rat VLDL (trace amounts) for $6 \mathrm{~h}$ in cultured fibroblasts as above. No evidence of lipase action during the incubation was found (data not shown). In the second experiment, ${ }^{125} \mathrm{I}-\mathrm{VLDL}$ was incubated with buffer, $\mathrm{HDL}_{3}$, and BSA under conditions identical to the lipolysis mixture except that lipoprotein lipase was absent and the albumin contained oleic acid (sodium salt) in amounts equivalent or double those expected to be generated during active lipolysis. The metabolism of these preparations remained unchanged when compared to control VLDL (data not shown).

The metabolism of lipolyzed rat VLDL after $2 \mathrm{~h}$ recirculation in supradiaphragmatic animals as determined in cultured human skin fibroblasts is shown in Table IV. The results are qualitatively similar to those observed for lipolyzed human VLDL subfractions, i.e., appreciably higher metabolic activities of the lipolyzed VLDL but only modest enhancement by exogenous apo E-3. Very similar results were recorded with cultured rat skin fibroblasts except that, as previously reported (25), human LDL was unreactive on rat cells.

Table II. Cellular Binding, Association, and Degradation of Control and Lipolyzed Human ${ }^{125}$ I-VLDL Subfractions. Studies in Cultured Fibroblasts

\begin{tabular}{|c|c|c|c|c|c|c|c|c|c|c|c|c|}
\hline \multirow[b]{3}{*}{ Lipoprotein } & \multicolumn{4}{|c|}{ Binding } & \multicolumn{4}{|c|}{ Association } & \multicolumn{4}{|c|}{ Degradation } \\
\hline & \multicolumn{2}{|c|}{ Control } & \multicolumn{2}{|c|}{ Lipolyzed } & \multicolumn{2}{|c|}{ Control } & \multicolumn{2}{|c|}{ Lipolyzed } & \multicolumn{2}{|c|}{ Control } & \multicolumn{2}{|c|}{ Lipolyzed } \\
\hline & $-E-3$ & $+\mathrm{E}-3$ & $-E-3$ & $+\mathrm{E}-3$ & $-E-3$ & $+\mathrm{E}-3$ & $-E-3$ & $+E-3$ & $-E-3$ & $+\mathrm{E}-3$ & $-E-3$ & $+\mathrm{E}-3$ \\
\hline & \multicolumn{12}{|c|}{ ng apo B-100/mg cell protein } \\
\hline VLDL-I (7) & $6 \pm 2$ & $13 \pm 3$ & $23 \pm 3$ & $39 \pm 5$ & $13 \pm 3$ & $36 \pm 9$ & $49 \pm 8$ & $110 \pm 11$ & $12 \pm 4$ & $227 \pm 62$ & $251 \pm 45$ & $574 \pm 66$ \\
\hline VLDL-II (8) & $12 \pm 2$ & $33 \pm 6$ & $28 \pm 4$ & $53 \pm 13$ & $14 \pm 2$ & $60 \pm 9$ & $27 \pm 4$ & $82 \pm 12$ & $18 \pm 6$ & $482 \pm 67$ & $204 \pm 40$ & $640 \pm 97$ \\
\hline VLDL-III (7) & $10 \pm 2$ & $38 \pm 7$ & $39 \pm 6$ & $55 \pm 11$ & $17 \pm 3$ & $85 \pm 12$ & $44 \pm 6$ & $106 \pm 4$ & $63 \pm 22$ & $647 \pm 115$ & $289 \pm 63$ & $816 \pm 124$ \\
\hline LDL & $31 \pm 4$ & - & - & - & $58 \pm 5$ & - & - & - & $709 \pm 90$ & - & - & - \\
\hline
\end{tabular}

Data are mean $\pm \mathrm{SEM}$ of the number of experiments shown in parentheses. Incubations were carried out at $37^{\circ} \mathrm{C}$ in upregulated $(48 \mathrm{~h})$ cultured human skin fibroblasts for $6 \mathrm{~h}$ as described in Methods. 
Table III. Cellular Binding, Association and Degradation of Control and Lipolyzed Human ${ }^{125}$ I-VLDL: Studies in HepG-2 Cultures

\begin{tabular}{lccccc}
\hline & \multicolumn{2}{c}{ Control } & & \multicolumn{2}{c}{ Lipolyzed } \\
\cline { 2 - 3 } \cline { 5 - 6 } & $-\mathrm{E}-3$ & $+\mathrm{E}-3$ & & $-\mathrm{E}-3$ & $+\mathrm{E}-3$ \\
\hline Binding & $10 \pm 1$ & $22 \pm 2$ & & $18 \pm 2$ & $36 \pm 5$ \\
Association & $16 \pm 2$ & $38 \pm 6$ & & $28 \pm 6$ & $47 \pm 12$ \\
Degradation & $31 \pm 10$ & $115 \pm 18$ & & $85 \pm 24$ & $172 \pm 36$
\end{tabular}

Data are means \pm SEM of 10 experiments. The VLDL preparations studied were VLDL-I, two preparations; VLDL-II, four preparations; VLDL-III, four preparations. The results with the three different VLDL density fractions were very similar and the data from all 10 experiments were combined. Incubations were carried out at $37^{\circ} \mathrm{C}$ in unregulated ( $48 \mathrm{~h}$ ) HepG-2 cultures for $6 \mathrm{~h}$ as described in Methods. Binding, association, and degradation of LDL used in the same experiments were $16 \pm 3,39 \pm 9$, and $190 \pm 26 \mathrm{ng}$ apo $\mathrm{B} / \mathrm{mg}$ cell protein, respectively.

In the next experiment we have determined the kinetics of apo E-3 stimulatory effects on the cellular metabolism of control and lipolyzed VLDL. Fig. 2 shows the proteolytic degradation data. An additional difference between the two was observed. While the enhancing effect of exogenous apo E-3 on control VLDL was gradual and increased with increasing apo E-3 concentration in the culture medium (from 0.5 to $4 \mu \mathrm{g}$ protein $/ \mathrm{ml}$ ), the maximal effect of exogenous apo E-3 on lipolyzed VLDL was observed already with the lowest apo E-3 concentration examined in this experiment, $0.5 \mu \mathrm{g} / \mathrm{ml}$. Lower apo E-3 concentrations tested in other experiments resulted in intermediate activity (not shown). Similar results were obtained for binding and cell association.

Binding, association, and degradation of control and lipolyzed VLDL appeared to be a saturable process either without or with exogenous apo E-3 (Fig. 3, proteolytic degradation data). These observations indicate that the cell metabolism of the lipolyzed VLDL occurred by specific receptors. Competition of the binding and proteolytic degradation of control and lipolyzed ${ }^{125}$ I-VLDL by unlabeled control and lipolyzed VLDL supports that conclusion (data not shown). In addition, binding, cell association, and degradation of both control and lipolyzed ${ }^{125} \mathrm{I}-\mathrm{VLDL}$ by $\mathrm{LDL}$ receptor-negative fibroblasts was minimal (Table V).

The relationships between degrees of lipolysis and cell metabolism of the lipolyzed VLDL were evaluated in eight experiments without added apo E-3 and 10 experiments with exogenous apo E-3 (data not shown). A weak but not significant positive effect of lipolysis on the degradation of lipolyzed VLDL without added apo $E$ is suggested $(r=0.33)$. No relationships were found for apo E-3-enriched preparations.

The ligand responsible for the uptake of lipolyzed VLDL by the cells, apo B-100 or apo E, was determined by employing monoclonal antibodies that specifically block receptor uptake and degradation of lipoproteins by apo B-100 (antibody 4G3) or apo E (antibody 1D7). Antibody 1D7 decreased by 80-90\% both the low degradation values of control and the high degradation values of lipolyzed VLDL-I + II while antibody 4G3 had a minimal (5-20\%) effect. With control and lipolyzed VLDL-III $\sim 60-70 \%$ of the metabolic activity was blocked by antibody $1 \mathrm{D} 7$ and $30-40 \%$ by antibody $4 \mathrm{G} 3$. A combination of the two antibodies totally blocked the uptake and degradation of all these VLDL preparations and antibody 4G3 effectively prevented LDL metabolism, whereas antibody 1D7 was almost totally inert. Fig. 4 demonstrates that antibody 1D7, already at protein concentration of $1-2.5 \mu \mathrm{g} / \mathrm{ml}$ dramatically decreased VLDL degradation by the cells. Antibody 4G3 was considerably less effective. The experiment thus proved that the catabolism of VLDL by the cells is mediated predominantly by apo $E$ and that lipolysis causes a dramatic increase of the biological expression of apo $\mathrm{E}$ at the lipoprotein surface. The role of apo B-100 in the process is minimal (VLDL-I + II) or moderate (VLDL-III).

To determine whether apo $\mathrm{E}$ is transferred to lipolyzed VLDL from the HDL present in the lipolysis mixture or the LPDS present in the cell medium, the metabolic behavior of VLDL from a normal apo E-3/3 and a type III hyperlipidemia apo E-2/2 profile was determined. With the normal VLDL, lipolysis and cell culture experiments were investigated twice; first with $\mathrm{HDL}_{3}$ and LPDS from an E-3/3 subject and second with $\mathrm{HDL}_{3}$ and LPDS from the type III E-2/2 patient. The type

Table IV. Cellular Binding, Association, and Degradation of Control and Lipolyzed Rat ${ }^{125}$ I-VLDL

\begin{tabular}{|c|c|c|c|c|c|c|}
\hline \multirow[b]{2}{*}{ VLDL } & \multicolumn{2}{|c|}{ Binding } & \multicolumn{2}{|c|}{ Association } & \multicolumn{2}{|c|}{ Degradation } \\
\hline & $-E-3$ & $+\mathrm{E}-3$ & $-E-3$ & $+\mathrm{E}-3$ & $-\mathrm{E}-3$ & $+\mathrm{E}-3$ \\
\hline & \multicolumn{6}{|c|}{ ng protein/mg cell protein } \\
\hline \multicolumn{7}{|c|}{ Human fibroblasts } \\
\hline Control (5) & $25 \pm 6$ & $40 \pm 6$ & $290 \pm 48$ & $445 \pm 29$ & $1326 \pm 246$ & $2318 \pm 247$ \\
\hline Lipolyzed (6) & $47 \pm 9$ & $63 \pm 13$ & $645 \pm 105$ & $750 \pm 68$ & $2657 \pm 496$ & $3370 \pm 379$ \\
\hline LDL & $33 \pm 7$ & - & $225 \pm 35$ & - & $3054 \pm 383$ & - \\
\hline \multicolumn{7}{|l|}{ Rat fibroblasts } \\
\hline Control (3) & $26 \pm 6$ & $38 \pm 16$ & $203 \pm 48$ & $284 \pm 76$ & $579 \pm 160$ & $887 \pm 266$ \\
\hline Lipolyzed (4) & $30 \pm 4$ & $52 \pm 12$ & $459 \pm 126$ & $661 \pm 212$ & $1063 \pm 291$ & $1756 \pm 636$ \\
\hline
\end{tabular}

Data are mean $\pm \mathrm{SEM}$ of the number of experiments shown in parentheses. Incubations were carried out at $37^{\circ} \mathrm{C}$ in upregulated ( $48 \mathrm{~h}$ ) cultured human or rat skin fibroblasts for $24 \mathrm{~h}$ as described in Methods. 


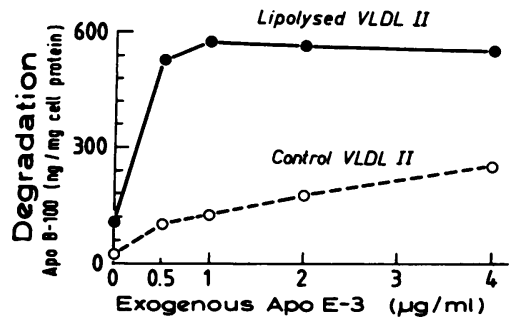

fibroblasts and the VLDL was used at apo B-100 concentration of 10 $\mu \mathrm{g} / \mathrm{ml}$. Degradation was determined as described in Methods. Triglyceride hydrolysis, $35 \%$.

III VLDL was lipolyzed and investigated in the cells with apo E-2/2 $\mathrm{HDL}_{3}$ and LPDS. Both the normal and type III VLDLs were studied without and with exogenous apo E-3. The results of this experiment are shown in Table VI. The metabolic behavior of the normal (E-3/3) VLDL in the presence of normal (E-3/3) $\mathrm{HDL}_{3}$ and LPDS was similar to that described above, i.e., lipolyzed VLDL exhibited pronounced metabolic parameters, with an additional effect of exogenous apo E-3. When the lipolysis and cell culture studies of the normal E-3/3 VLDL were investigated with $\mathrm{E}-2 / 2 \mathrm{HDL}_{3}$ and LPDS, similar effects were observed. With the type III (E-2/2) VLDL barely detectable metabolic activities were found and no effect of lipolysis was observed when the study was conducted with E-2/2 $\mathrm{HDL}_{3}$ and LPDS. When exogenous apo E-3 was added, the control type III VLDL exhibited activities that were similar to the normal E-3/3 VLDL and a definite effect of lipolysis was found.

\section{Discussion}

The studies by Mahley and colleagues have established the importance of functional apo $\mathrm{E}$ molecules as ligands for the interaction of a variety of lipoproteins and lipoprotein remnants

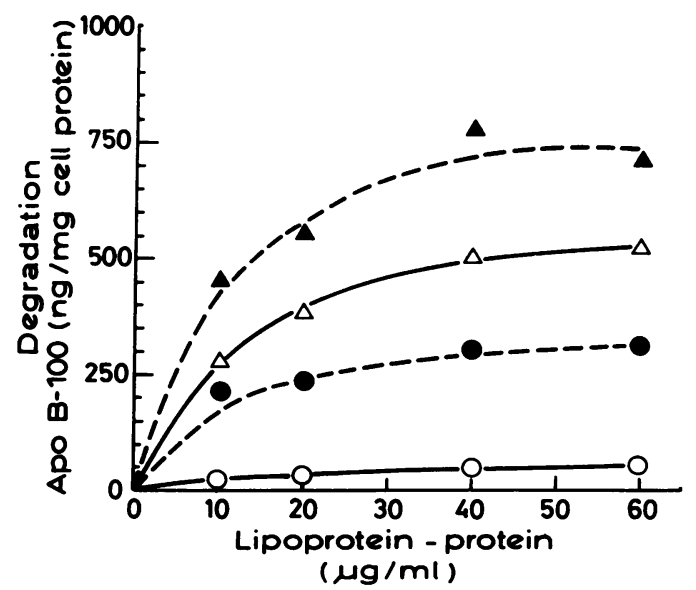

Figure 3. Concentration-dependent degradation of control and lipolyzed VLDL-II in the absence and presence of exogenous recombinant apo E-3. Apo E-3 to VLDL protein ratio was kept constant, 4:10. The lipoprotein was incubated for $6 \mathrm{~h}$ at $37^{\circ} \mathrm{C}$ with up-regulated fibroblasts and proteolytic degradation was determined as described in Methods. ( $(-\circ)$ Control VLDL; ( - $\bullet$ ) control VLDL + apo E-3; $(\Delta-\Delta)$ lipolyzed VLDL; $(\Delta-\Delta)$ lipolyzed VLDL + apo E-3. Triglyceride hydrolysis, $50 \%$.
Table V. Cellular Binding, Association, and Degradation of Human ${ }^{125} I-V L D L-I I$ in Normal and Receptor Negative (FH) Skin Fibroblasts

\begin{tabular}{|c|c|c|c|c|c|c|c|}
\hline \multirow[b]{2}{*}{ VLDL } & \multirow[b]{2}{*}{ Fibroblasts } & \multicolumn{2}{|c|}{ Binding } & \multicolumn{2}{|c|}{ Association } & \multicolumn{2}{|c|}{ Degradation } \\
\hline & & $-E-3$ & $+\mathrm{E}-3$ & $-E-3$ & $+E-3$ & $-E-3$ & $+\mathrm{E}-3$ \\
\hline & & \multicolumn{6}{|c|}{ ng apo B-100/mg cell protein } \\
\hline \multirow[t]{2}{*}{ Control } & Normal & 13 & 41 & 13 & 90 & 13 & 518 \\
\hline & FH & 4 & 5 & 5 & 6 & 0 & 3 \\
\hline \multirow[t]{2}{*}{ Lipolyzed } & Normal & 32 & 59 & 40 & 83 & 250 & 603 \\
\hline & FH & 2 & 3 & 6 & 9 & 0 & 7 \\
\hline \multirow[t]{2}{*}{ LDL } & Normal & 54 & - & 175 & - & 1450 & - \\
\hline & FH & 1 & - & 1 & - & 1 & - \\
\hline
\end{tabular}

Data are means of duplicate dishes. The difference in values between the duplicates was $<10 \%$. Incubations were carried out at $37^{\circ} \mathrm{C}$ in upregulated $(48 \mathrm{~h})$ cultured human skin fibroblasts for $6 \mathrm{~h}$ as described in Methods.

with specific cell receptors $(7,8)$. Yet, the structural/compositional determinants that are responsible for biological expression of apo $\mathrm{E}$ at lipoprotein surfaces are largely unknown. It has previously been shown that apo E present on VLDL (9-11) and IDL (12) from normolipidemic humans does not cause an avid interaction of the lipoproteins with the LDL receptor on fibroblasts. Similarly, Knowl et al. (13) observed that apo E-rich rabbit $\beta$-VLDL is not readily metabolized by the LDL-receptor related protein (LRP) in fibroblasts from receptor-negative $\mathrm{FH}$ patients. In both studies (11-13), however, addition of exogenous apo E-3 to the lipoproteins initiated a prompt uptake and degradation (or cholesterol entry) of the lipoproteins by the cells. Intravenous infusion of exogenous apo E-3 to WHHL and cholesterol-fed rabbits, moreover, also initiates a rapid clearance from the blood plasma of lipoproteins that are rich in apo E $(26,27)$. Evidently, metabolic effects that are poorly understood are necessary for proper biological expression of endogenous apo $\mathrm{E}$ molecules in lipoproteins.

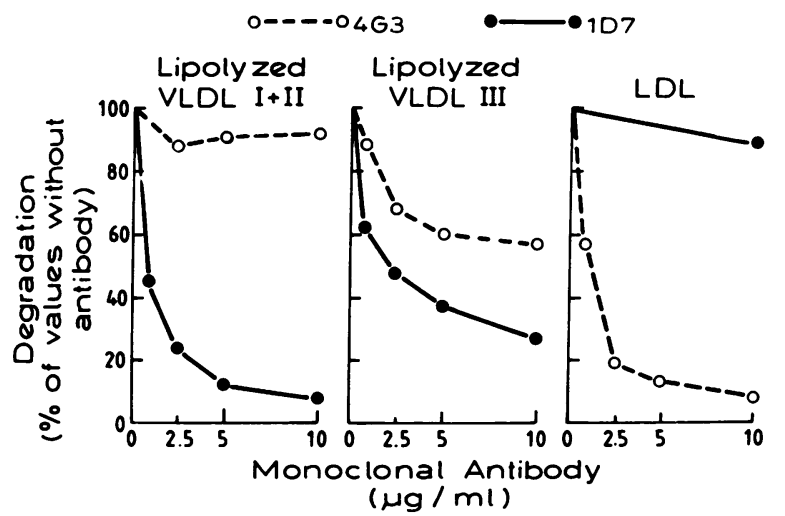

Figure 4. Effects of increasing concentrations of antibodies 1D7 and $4 \mathrm{G} 3$ on the proteolytic degradation of ${ }^{125}$ I-labeled lipolyzed VLDL-I + II, lipolyzed VLDL-III, and LDL. Data are percent of degradation values measured without antibodies. The labeled lipoproteins were incubated with upregulated $(48 \mathrm{~h})$ fibroblasts at $37^{\circ} \mathrm{C}$ for $6 \mathrm{~h}$ in the absence or presence of the indicated amounts of antibodies as described in Methods. Triglyceride hydrolysis, $60-70 \%$. 
Table VI. Cellular Binding, Association, and Degradation of Apo E-3/3 and Apo E-2/2 VLDL after Lipolysis in the Presence of Apo E-3/3 or Apo E-2/2 HDL and LPDS

\begin{tabular}{|c|c|c|c|c|c|c|c|c|}
\hline \multirow[b]{2}{*}{ VLDL } & \multirow[b]{2}{*}{ HDL/LPDS } & & \multicolumn{2}{|c|}{ Binding } & \multicolumn{2}{|c|}{ Association } & \multicolumn{2}{|c|}{ Degradation } \\
\hline & & & -apo E & +apo E & -apo E & tapo E & -apo E & tapo E \\
\hline & & & \multicolumn{6}{|c|}{ ng apo B-100/mg cell protein } \\
\hline \multirow[t]{3}{*}{ apo E-3/3 } & apo E-3/3 & Control & 2 & 20 & 7 & 117 & 25 & 416 \\
\hline & & Lipolysis & 24 & 39 & 77 & 158 & 322 & 572 \\
\hline & apo E-2/2 & Lipolysis & 22 & 32 & 63 & 115 & 403 & 566 \\
\hline \multirow[t]{2}{*}{ apo E-2/2 } & apo E-2/2 & Control & 0 & 15 & 4 & 56 & Trace & 317 \\
\hline & & Lipolysis & 3 & 24 & 5 & 107 & Trace & 564 \\
\hline
\end{tabular}

Data are means of duplicate dishes containing ${ }^{125} \mathrm{I}-\mathrm{VLDL}-\mathrm{II}$ and incubated at $37^{\circ} \mathrm{C}$ for $6 \mathrm{~h}$. The difference between the duplicates was $<10 \%$.

Very similar results were obtained from VLDL-I + VLDL-II and VLDL-III preparations.

The results reported here are part of an attempt to elucidate the determinants that are responsible for apo E-mediated cellular metabolism of the triglyceride-rich lipoproteins VLDL and IDL. The data clearly demonstrate that in agreement with previous observations $(28,29)$ lipolysis results in a greatly enhanced uptake and degradation of VLDL by the LDL receptor pathway. This effect is observed regardless of the source of lipolytic activity, bovine milk lipoprotein lipase in vitro or endothelial-bound lipases in the supradiaphragmatic rat. The ligand responsible for the uptake and degradation of VLDL and their remnants by cellular receptors, apo B-100 or apo E, is not clear. Previous studies suggested that apo B-100 is involved with receptor interaction of heavy VLDL populations (30) and of lipolyzed VLDL (29). Our data, however, clearly prove that apo $E$ is the ligand responsible for the stimulated uptake of lipolyzed VLDL by the cell receptors with only a minor or moderate contribution of apo B-100. The difference between the present and previous studies reflects perhaps unproportionally high loss of apo E from VLDL in the latter, leaving predominantly apo $\mathrm{B}-100$ in the VLDL. The view that apo $\mathrm{E}$ is the major apoprotein that directs VLDL and VLDL remnants to receptors is supported by observations in patients with type III hyperlipidemia (31) and on the stimulation of VLDL-cell interaction by exogenous apo E-3 (11-13).

The apo $\mathrm{E}$ in the postlipolysis VLDL particle may have represented the molecules associated with the particles isolated from plasma (endogenous apo E) or it could have been transferred from the $\mathrm{HDL}_{3}$ and/or LPDS present in the lipolysis mixture and the cell culture medium. The results of the study carried out with HDL and LPDS from an apo E-2/2 subject prove unequivocally that the endogenous apo $\mathrm{E}$ present in the VLDL is responsible for the stimulated uptake and degradation of the lipolyzed VLDL by the cells and that this process cannot be due to enhanced transfer of apo $\mathrm{E}$ from the $\mathrm{HDL}_{3}$ and/or LPDS. We therefore must conclude that lipolysis caused exposure of unreactive endogenous apo $\mathrm{E}$ molecules in the VLDL particles themselves and that a change initiated by the lipolytic process altered apo E-3 molecules already present at the lipoprotein surface.

Similar to previous observations (11) it is found that addition of exogenous apo E-3 to the cell culture medium caused enhancement of the metabolism of VLDL and lipolyzed
VLDL by the cells. In contrast to endogenous apo E-3, however, the increment metabolism induced by exogenous apo E-3 was almost identical for control and lipolyzed VLDL. In absolute terms, exogenous apo E-3 increased VLDL-I, II, and III degradation of the control-incubated preparations by 215,464 , and $584 \mathrm{ng}$ apo $\mathrm{B} / \mathrm{mg}$ cell protein per $6 \mathrm{~h}$, the corresponding values for postlipolysis preparations were very similar, 323 , 436 , and $527 \mathrm{ng}$ apo B/mg cell protein per $6 \mathrm{~h}$, respectively (derived from Table II). The basal degradation values are, however, very different and higher in postlipolysis preparations by 5-20-fold! The failure to induce a significantly higher metabolic activity of lipolyzed VLDL by exogenous apo E-3 indicates that unlike endogenous apo $\mathrm{E}$, its biological expression remains relatively unaffected by lipolysis. These considerations raise the interesting possibility that endogenous and exogenous apo $\mathrm{E}$ are not oriented similarly at the surface of triglyceriderich lipoproteins and that the exogenous apo E-3 is better (although not fully [11, 12]) expressed in control VLDL but is less sensitive to lipolysis effects. Yet, the rate of association of apo $E$ with lipolyzed VLDL is possibly higher and explains the finding that lower concentrations of exogenous apo E-3 are sufficient for maximal stimulation of their cellular metabolism. Whether apo E transferred from HDL to VLDL and chylomicrons behaves like the endogenous protein or the exogenous molecule is not known.

The mechanism responsible for the induction of biological expression of endogenous apo $\mathrm{E}$ by lipolysis is unclear. One possibility is a conformational change of the protein that exposes unreactive ligand-binding domains; another is deletion of $\mathrm{C}$ apoproteins (a known consequence of lipolysis [24]) that were shown to inhibit apo E-mediated interactions of lipoproteins with cellular receptors (32-34). If the latter possibility is correct, however, we would have expected to find also a very substantial effect on the behavior of exogenous apo E-3 molecules. Noteworthy, in studies currently conducted by us it was found that apo $\mathrm{C}$ has a strong inhibitory effect on apo E-3-stimulated cell metabolism of VLDL (submitted for publication). We therefore suggest that the lipolysis process alters the conformation of endogenous apo $\mathrm{E}$ molecules at lipoprotein surfaces and that this change induces catabolism of the lipoproteins by specific receptor-dependent pathways. A lipolysis-induced conformation change has been previously demonstrated for 


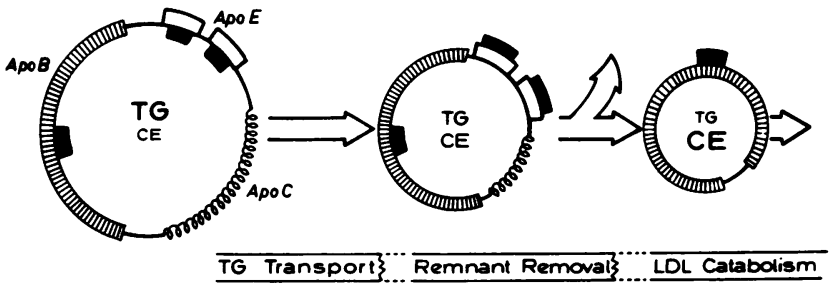

Figure 5. Regulation by lipolysis of triglyceride transport, remnant catabolism, and LDL formation along the VLDL $\rightarrow$ IDL $\rightarrow$ LDL cascade. In intact VLDL, both apo $B$ and apo $E$ are nonreactive and their receptor-binding domains (solid bars) are oriented away from the water phase. These particles therefore will interact predominantly with lipoprotein lipase. As lipolysis progresses, the ligand-binding domain of apo $\mathrm{E}$ in VLDL becomes exposed, apo $\mathrm{C}$ molecules are removed, and the lipoprotein enters a remnant removal process that determines the number of particles that are converted to LDL. Exposure of the receptor-binding domain of apo B occurs later in the cascade and a reactive apo B is the only receptor-binding ligand in LDL.

apo B-100 (29). It is possible that the conformation of both apo B-100 and apo $\mathrm{E}$ is altered by the lipolysis process but only the latter results in a substantially increased affinity toward cell receptors, whereas the change of apo B-100 has only a minimal or moderate affect on the receptor-binding domain of the protein.

The experiments described in this report suggest a novel mechanism that regulates VLDL metabolism and metabolic fate along the VLDL $\rightarrow$ IDL $\rightarrow$ LDL cascade (Fig. 5). The intact particle contains apo $\mathrm{B}$, apo $\mathrm{C}$, and apo $\mathrm{E}$ molecules. However, both apo B and apo $\mathrm{E}$ are oriented such that their receptor-binding domains are unreactive. Apo $C$, especially $C$ II in contrast, is reactive and therefore the particles avidly interact with lipoprotein lipases in extrahepatic tissues and transport triglycerides to the tissue. As lipolysis progresses the orientation of endogenous apo $\mathrm{E}$ molecules is changed and their unreactive receptor-binding domains become exposed. Yet, the orientation of apo B does not change, or if changed (29) does not expose its receptor-binding domain. This exposure of unreactive domains in apo $\mathrm{E}$ together with loss of apo $\mathrm{C}$ molecules directs the particles to catabolic, receptor-dependent sites. Our data suggest that this process may occur gradually in relation to the degree of lipolysis. Although our experiments examined predominantly the interaction of the VLDL with LDL receptors in fibroblasts it is tempting to speculate that lipolysis would influence similarly VLDL catabolism by other apo E-specific receptors, for example the LDL receptor-related protein in liver (35). If that indeed occurs in vivo, then the mechanism proposed above would regulate both triglyceride transport and remnant removal processes and determine the number of LDL particles formed by the apo B-100 cascade.

\section{Acknowledgments}

The excellent technical assistance of Ms. R. Avner, H. Lefkovitz, and E. Butbul is greatly appreciated.

The investigations were supported in part by a grant from the $\mathrm{Na}$ tional Council for Research and Development and the G.S.F., Munich, FRG, No. DISMED 61/GR 434. Exogenous recombinant apo E-3 is a generous gift of Dr. T. Vogel and Dr. M. Gorecki from Biotechnology General, Rehovot, Israel. Bovine milk lipoprotein lipase is a generous gift of Dr. T. Olivecrona, Umea, Sweden. Monoclonal antibodies 1D7 and 4G3 are a generous gift of Drs. Milne and Marcel.

\section{References}

1. Eisenberg, S. 1976. Mechanisms of formation of low density lipoproteins: metabolic pathways and their regulation. In Low Density Lipoprotein. C. E. Day and R. J. Levy, editors. New York. Plenum Publishing Press, 73-92.

2. Brown, M. S., and J. L. Goldstein. 1986. A receptor-mediated pathway for cholesterol homeostasis. Science (Wash. DC). 232:34-47.

3. Havel, R. J. 1985. Role of the liver in atherosclerosis. Arteriosclerosis. 5:569-580.

4. Eisenberg, S., and D. Rachmilewitz. 1973. Metabolism of rat plasma very low density lipoprotein. II. Fate in circulation of apoprotein subunits. Biochim. Biophys. Acta. 326:391-405.

5. Yamada, N., D. M. Shames, J. B. Stoudemire, and R. J. Havel. 1986. Metabolism of lipoproteins containing apolipoprotein B-100 in blood plasma of rabbits: heterogeneity related to the presence of apolipoprotein. E. Proc. Natl. Acad. Sci. USA. 83:3479-3483.

6. Vega, G. L., and S. M. Grundy. 1987. Mechanisms of primary hypercholesterolemia in humans. Am. Heart J. 113:493-502.

7. Mahley, R. W., and T. L. Innerarity. 1983. Lipoprotein receptors and cholesterol homeostasis. Biochim. Biophys. Acta. 737:197-222.

8. Innerarity, T. L., K. S. Arnold, K. H. Weisgraber, and R. W. Mahley. 1986. Apolipoprotein $\mathrm{E}$ is the determinant that mediates the receptor uptake of $\beta$-very low density lipoproteins by mouse macrophages. Arteriosclerosis. 6:114-120.

9. Gianturco, S. H., A. M. Gotto, Jr., R. L. Jackson, J. R. Patsch, H. D. Sybers, O. D. Taunton, D. L. Yeshurun, and L. C. Smith. 1978. Control of 3-hydroxy-3methylglutaryl-CoA reductase activity in cultured human fibroblasts by very low density lipoproteins of subjects with hypertriglyceridemia. J. Clin. Invest. 61:320-328.

10. Gianturco, S. H., A. M. Gotto, Jr., S.-L. C. Hwang, J. B. Karlin, A. H. Y. Lim, S. C. Prasad, and W. A. Bradley. 1983. Apolipoprotein E mediates uptake of $S_{f}, 100-400$ hypertriglyceridemic very low density lipoprotein by the low density lipoprotein receptor pathway in normal human fibroblasts. J. Biol. Chem. 258:4526-4533.

11. Eisenberg, S., G. Friedman, and T. Vogel. 1988. Enhanced metabolism of normolipidemic human plasma very low density lipoprotein in cultured cells by exogenous apolipoprotein E-3. Arteriosclerosis. 8:480-487.

12. Friedman, G., D. Gavish, T. Vogel, and S. Eisenberg. 1990. Cellular metabolism of human plasma intermediate-density lipoprotein (IDL). Biochim. Biophys. Acta. 1044:118-126.

13. Kowal, R. C., J. Herz, J. L. Goldstein, V. Esser, and M. S. Brown. 1989. Low density lipoprotein receptor-related protein mediates uptake of cholesteryl esters derived from apoprotein E-enriched lipoproteins. Proc. Natl. Acad. Sci. USA. 86:5810-5814.

14. Lindgren, F. T., L. C. Jensen, and F. T. Hatch. 1972. The isolation and quantitative analysis of serum lipoproteins. In Blood Lipids and Lipoproteins: Quantitation, Composition and Metabolism. Wiley-Interscience, New York. 181-274.

15. Weber, K., and M. Osborn. 1969. The reliability of molecular weight determinations by dodecyl sulfate-polyacrylamide gel electrophoreses. J. Biol. Chem. 244:4406-4412.

16. Vogel, T., K. H. Weisgraber, M. I. Zeevi, et al. 1985. Human apolipoprotein E expression in Escherichia coli: structural and functional identity of the bacterially produced protein with plasma apolipoprotein E. Proc. Natl. Acad. Sci. USA. 82:8696-8700.

17. MacFarlane, A. S. 1985 . Efficient trace labeling of proteins with iodine Nature (Lond.). 182:53.

18. Bilheimer, D. W., S. Eisenberg, and R. I. Levy. 1972. The metabolism of very low density lipoprotein proteins. Biochim. Biophys. Acta. 260:212-221.

19. Oschry, Y., T. Olivecrona, R. J. Deckelbaum, and S. Eisenberg. 1985. Is hypertriglyceridemic very low density lipoprotein a precursor of normal low density lipoproteins? J. Lipid Res. 26:158-167.

20. Bezman-Tarcher, A., and D. S. Robinson. 1965. A technique for the preparation of the functional supradiaphragmatic portion of the rat. Proc. $R$. Soc. Lond. B. 162:406-410.

21. Kleinman, Y., S. Eisenberg, Y. Oschry, D. Gavish, O. Stein, and Y. Stein. 1985. Defective metabolism of hypertriglyceridemic low density lipoprotein in cultured human skin fibroblasts. J. Clin. Invest. 75:1796-1803.

22. Goldstein, J. L., S. K. Basu, and M. S. Brown. 1983. Receptor-mediated endocytosis of low-density lipoprotein in cultured cells. Methods Enzymol. 98:241-260.

23. Milne, R. W., P. Douste-Blazy, Y. L. Marcel, and L. Retegui. 1981. Characterization of monoclonal antibodies against human apolipoprotein E. J. Clin. Invest. 68:111-117.

24. Chajek, T., and S. Eisenberg. 1978. Very low density lipoprotein. Metabo- 
lism of phospholipids, cholesterol and apolipoprotein $\mathrm{C}$ in the isolated perfused rat heart. J. Clin. Invest. 61:1654-1665.

25. Innerarity, T. L., R. E. Pitas, and R. W. Mahley. 1980. Disparities in the interaction of rat and human lipoproteins with cultured rat fibroblasts and smooth muscle cells. J. Biol. Chem. 255:11163-11172.

26. Yamada, N., H. Shimano, H. Mokuno, S. Ishibashi, T. Gotohda, M. Kawakami, Y. Watanabe, Y. Akanuma, T. Murase, and F. Takaku. 1989. Increase clearance of plasma cholesterol after injection of apolipoprotein $E$ into Watanabe heritable hyperlipidemic rabbits. Proc. Natl. Acad. Sci. USA. 86:665669.

27. Mahley, R. W., K. H. Weisgraber, M. M. Hussain, B. Greenman, M. Fisher, T. Vogel, and M. Gorecki. 1989. Intravenous infusion of apolipoprotein E accelerates clearance of plasma lipoproteins in rabbits. J. Clin. Invest. 83:21252130.

28. Bierman, E. L., S. Eisenberg, O. Stein, and Y. Stein. 1973. Very low density lipoprotein particles: uptake by aortic smooth muscle cells in culture. Biochim. Biophys. Acta. 329:163-169.

29. Schonfeld, G., W. Patsch, B. Pfleger, J. L. Witztum, and S. W. Weidman. 1979. Lipolysis produces changes in the immunoreactivity and cell reactivity of very low density lipoproteins. J. Clin. Invest. 64:1288-1297.
30. Krul, E. S., M. J. Tikkanen, T. G. Cole, J. M. Davie, and G. Schonfeld. 1985. Roles of apolipoproteins $B$ and $E$ in the cellular binding of very low density lipoproteins. J. Clin. Invest. 75:361-369.

31. Mahley, R. W., and B. Angelin. 1984. Type III hyperlipoproteinemia: recent insights into the genetic defect of familial dysbetalipoproteinemia. $A d v$. Int. Med. 29:385-411.

32. Windler, E., Y.-S. Chao, and R. J. Havel. 1980. Regulation of the hepatic uptake of triglyceride-rich lipoproteins in the rat. J. Biol. Chem. 255:8303-8307.

33. Windler, E., and R. J. Havel. 1985. Inhibitory effects of $C$ apolipoproteins from rats and humans on the uptake of triglyceride-rich lipoproteins and their remnants by the perfused rat liver. J. Lipid Res. 26:556-565.

34. Kowal, R. C., J. Herz, K. H. Weisgraber, R. W. Mahley, M. S. Brown, and J. L. Goldstein. 1990. Opposing effects of apopolipoproteins E and C on lipoprotein binding to low density lipoprotein receptor-related protein. J. Biol. Chem. 265:10771-10779.

35. Hertz, J., U. Hamann, S. Rogne, O. Nyklebost, H. Gausepohl, and K. Stanley. 1988. Surface location and high affinity for calcium of a 500-kd liver membrane protein closely related to the LDL-receptor suggest a physiological role as lipoprotein receptor. EMBO (Eur. Mol. Biol. Organ.) J. 7:4119-4127. 